\title{
Post occupancy evaluation of Putra Perdana park
}

\begin{abstract}
In rapidly developed countries such as malaysia, the importance of urban parks is recognized by development of new parks expecially in Putrajaya. This paper analyses the status of Putra Perdana Parks in Putrajaya in terms of vistors satisfaction towards park setting including people's needs, accessibility, park safety, parks design and park facilities and mainteanace using Post Occupancy Evalution (POE) method. Data was compiled by meansof a literature review, observation and survey among visitors. Result shows Putra Perdana Parks is the effectiveness of a park's design with visitors were satisfaction with score 4 out of 5 using 5 rating likert scale performance. Challenges releted to this publication should guide the landscape architects as well as the contractors to see the importance of conducting POE in the future and to upgrade the existing parks in Malaysia.
\end{abstract}

Keyword: Accessibility; Maintenance; Park safety; Post occupancy evaluation; Satisfaction 